\title{
植物病原菌における薬剤耐性菌の検定法とその疫学
}

\author{
桜 井 寿 \\ 農林省農薬検査所 \\ （昭和 51 年 6 月 7 日受理）
}

\section{Methods of Determinating the Drug-resistant Strains in Phytopathogenic Bacteria and Fungi and its Epidemiology in the Field}

\author{
Hisashi SAKURAI \\ Agricultural Chemicals Inspection Station, Ministry of Agriculture \\ and Forestry, Kodaira, 187 Tokyo, Japan
}

\section{は じめに}

近年植物保護における病害防除薬剂として，残留毒性 の抢それがなく，選択毒性の高い薬剂が開発実用化され ている。これらの化学療法剤は病原菌の生育は阻害する が，寄主に対しては一般的に阻害作用を示さない。 ま た，各種の化学療法剤にはそれぞれ特有の抗菌スペクト ルがあって，ある病原菌に対して阻害作用を示すが，他 の菌に対しては抗菌力を示さない．このように同じ生き た細胞であり，その基本的機構が同じであるにもかかわ らず，細胞の種類によって異なる毒性を示す．この現象 が Ehrlich 以来の基礎的理念である「選択毒性」であ り，その性質を有する物質が化学療法剂である．植物病 害防除においても，化学療法剂の発見は大きな成果をも たらした。

しかしながら植物病原菌も生物の一種である以上，外 部環境の変化に対応して変異し, 適応しやすいもののみ が生存しつゔけることから, 薬郕の攻撃に対して病原菌 も巧妙に变異し，生存・増殖して薬剂防除を困難にする ことは当然考兄れることであった。

有害生物が薬郕に抵抗性を示す現象の歴史を調べる と, 医薬領域における化学療法剤の広沉な使用開始後 20 年にして, 細菌類の中に非常な勢いで薬郕耐性菌が出現 している，また，害虫およびダ二類の有機合成殺虫剂に 対する抵抗性が薬郕使用後数年を経ずして発生し，防除 上大きな問題となっている，それに反し植物病原菌にお
ける薬剂耐性菌の出現は懸念されていたが，比較的最近 まで病害防除上それほど問題にならなかった。ところ が，ここ数年間に各地で選択性の高い抗生物質および有 機合成殺菌剂の薬効低下現像が発生し，その原因として 耐性菌の出現 ${ }^{1,2)}$ が認められ，病害防除上大きな問題と なっている，今後も各種の病原菌につぎつぎと耐性菌が 出現することが予想され，病害防除の面から，これら耐 性菌をいかに絶滅するか重要な問題をかかえているとい えよう。

最近植物病原菌の薬剂耐性に関する研究報告ならびに 情報は多くなっているが，浅学のためそれらを総括する ことは不可能に近い。そこで主として，わが国で開発・ 実用化された農薬用抗生物質を中心にした研究結果か ら，薬梸耐性菌の検定法ならびに疫学的動向をとりあげ て, 今後の耐性菌の調査・研究の参考にしたいと思うも のである。

\section{感性 と耐性}

生物が薬戍との接触に対して示す反応として，感受性 あるいは感性，抵抗性あるいは耐性という言葉は，農薬 科学の基礎研究者はもとより，その使用場面にたずさわ っている人々にとって，むはや慣用語である．基礎研究 において，病原菌と薬剂を試験管内で取扱っている研究 者には，その立場からの見方がある．また病原菌の薬郕 耐性は遺伝学々密接な関係があり，その立場からの見方 がある。一方ほ場で病害防除に薬郕を使用する立場か 
ら,「薬剤の防除効果が期待できれば感性菌, 期待できな ければ而性菌」とすれば問題はない。しかし薬剤の作用 性，施用方法および施用薬量が異なることによって，感 性と耐性の境界が研究者の見方によってかなり違ってく る.このようにきわめて不便な現象について, 薬剤感受 性值の頻度分布曲線から求められる感性と耐性の関係 と, ほ場における防除効果の予測の意味を含めた感性と 耐性を何らかの形で区別することも必要になる場合もあ ろう.

病原菌の薬剤耐性を一つの形質発現という立場から考 察すると，ある菌がある薬扸に感性であるか，耐性であ るかは，ある薬剤濃度の条件下で菌が生育するかしない かできめることで，いかなる耐性菌も薬剤濃度を高めれ ば生育が不可能になる。したがって薬㓮に対する病原菌 の感受性の程度は概念的には「感受性が高い」とか，「低 い」と表現されている。 それを定量的に示すために in vitro の薬剂感受性值，あるいは植物体上の防除効果を 示す值によって具体的に表現することが可能である．病 原菌株の示す薬剤感受性值または防除効果は一様ではな く，その程度が「一定度以上高い」場合を感性とし，「一 定度以下低い」場合を耐性という関係を少なくとも慣習 的に広く認めている。しかしながら，現実にはその「一 定度」という重要な限界線が見方によって大きく異なる 点に問題の核心がある. そのためには，「ほ場に㧍いて 薬剂の効果が期待できるのが感性菌，できないのが耐性 菌」という区別の仕方を可能とする目的として，薬剤感 受性值を適正均一な方法で正しく測定し，妥当適切に感 性菌と耐性菌を判定しなければならない.しかもその検 定法が実験者に実施可能な範囲で，検定能率の点からも 許される範囲内に簡易化した試験法を確立するために， 今後どのようにすればよいか，あるいはそれに関係した 問題点定整理しておく必要もあると考えられる。

なお，言葉の定義として，一般に生物が薬剤との接触 に対して示す反応は, 質的には感受性という言葉で表現 されている。桑原 ${ }^{3}$ は「感受性」という表現は, Susceptibility あるいは Sensitivity なる語に対応するもので，い うまでもなく化学療法に特有な言葉ではない，つまり， 外来の刺激に対する反応性はすべて感受性という言葉に 包括されるのである．\&た「sensitive」なる語に「感受 性」をあてることがあるが，感受性は sensitivity に相当 する語とし， sensitive には感性なる語をあてるべきであ ると，述べている，病害虫に対する作物の生理的な反応 に感受性あるいは抵抗性が慣用語として用いられている が，薬剤に対する病原菌の反応について感性（または感 受性）と耐性の語を用いることの適否について検討する
必要があるかもしれない。

\section{薬凨耐性菌の定義}

有害生物に対する有効な薬剤の開発目的は，医薬ある いは農薬としての応用にある. 少ない薬量で有害生物の 発育を阻止または殺菌することが目的である，対象生物 に有効な薬剤に抵抗性あるいは耐性を示す生物学的集団 について，WHO は「殺虫剤に対する抵抗性とは，その 正常な集団の大多数の虫を殺すような薬量に酎える能力 がその系統に発達したことをいう4)」と定義している。 そして抵抗性は殺虫剤の使用で昆虫集団にひき起こされ た発達した特性で, 遺伝的なものであるとしている.し たがって，ある昆虫集団がある薬戍にもともと耐性を 示す現象は「無反応性 (refractoriness) $\left.)^{4}\right\rfloor$ とう語で 表現して，抵抗性 (resistance) とは明確に区別してい る.

三橋5) は薬剤耐性に関する生物学的意義を細菌遺伝学 的立場から，次のように説明している，各地からランダ ムに集めた菌株の薬剤耐性值 (MAC) を表示すると, 理 論的には図 1 のようになるはずである。すなわち，bに

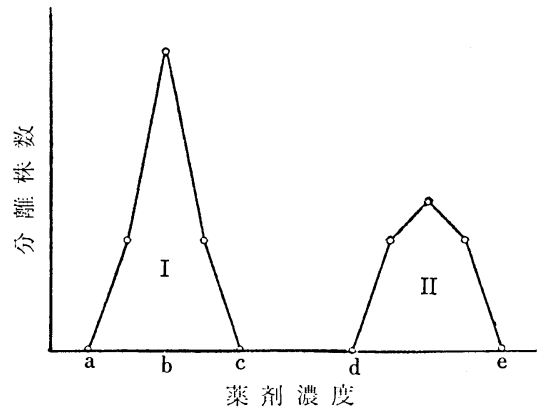

図 1 細菌の示す薬㓮感受性值の分布（三橋）

頂点をもつ一峰性の山を画く集団は c 以上の濃度では菌 は発育できない。この菌の集団のもつ薬剤に対する感受 性は $\mathrm{a} \sim \mathrm{c}$ の濃度範囲内に散在し，この性状は一定で， 遺伝的特性である。したがって薬剤濃度 c を越えた培地 に発育できるようになった菌，すなわち薬刘濃度 $\mathrm{d}$ 以上 に分布する菌の集団 II は集団 I に属さず，耐性菌と定義 できるとしている.

植物病原細菌および糸状菌において, 感性菌群と耐性 菌群を区別する境界濃度を設定している事例に，Georgopoulos $^{6)}$ らのベノミル耐性テンサイ褐斑病菌（Cercospora beticola) をはじめとし，わが国では Kuramoto?) のチオフォネートメチル耐性カンキツ青かび病菌 (Penicillium italicum) および緑かび病菌 (P. digitatum)の 報告がある，片桐ら ${ }^{8)}$ ， Miura ${ }^{9)} ら は$ 阻止円法でカスガ 
マイシン耐性イネいもち病菌 (Pyricularia oryzae) の検 定を行ない，阻止円を形成しない菌株を耐性菌としてい る. 筆者ら ${ }^{10 \sim 12)}$ は寒天平板希瀵法で，ストレプトマイシ ソおよびカスガマイシンに対する野菜の軟腐病菌 $(E r-$ winia carotovora)，キュウリ斑点細菌病菌 (Pseudomonas lachrymans)， ポリオキシン Bに対するリンゴ斑点 落葉病菌 (Alternaria mali), ナシ黑斑病菌 (A. kikuchiana)，カスガマイシンおよびブラストサイジン S に対す るイネいもち病菌 (Pyri. oryzae), carbendazim (MBC) および chlorothalonil に対する灰色かび病菌（Botrytis sp.) などの薬剤感受性值の頻度分布曲線を画くことによ って, 感性菌と耐性菌の境界濃度を判定または推定でき ることを報告した。

このように in vitro の薬戍感受性から感性か耐性か を判定される事例は多いが，フサライドなど in vitro の 薬郕感受性を測定する方法がみつかっていない薬郕の耐 性菌を考慮し，また現在採用されている in vitro の検 定法が植物体組織と同一の薬剤感受性を示す理想的な試 験法でないととから，試験規模や実験誤差から耐性菌它 感性菌と判定し，またその逆の事例も少数ではあるが認 められる。したがって，ほ場における防除効果の予測を 含めた耐性菌の検定を実施する立場から，私見として， 「農薬に扔いて薬戍耐性菌とは, 通常の薬剂施用によっ て防除効果の期待されない病原菌をいう」13) と定義した いことを提案した。

そのためには，植物体上における防除効果の感性と耐 性の境界を定量的に決めておくことが大切である。そこ で筆者らは薬効試験と耐性菌の検定においても, 薬郕の 有効性の判定基準は同一であることが望ましく，またほ 場に㧍ける病害防除効果の期待値を考慮し, 試案として 「理論的に求められる完全防除効果の $50 \%$ 未満または感 性菌標準株の防除効果の $50 \%$ 未満しか期待されない菌 株を耐性菌という」条件を設定し，in vitro の検定法か ら耐性菌と判定または推定された菌株について防除試験 を行なった。 その結果，同一菌株の in vitro と in vivo の薬剤感受性は相関することが認められた ${ }^{12,14)}$. しかし ながら供試菌株のすべてが，in vitro と in vivo の感 性と耐性が一致するとは限らなかったことから ${ }^{12)}$, より 多数の菌株定供試し, 試験例を蓄積し検定結果がほ場の 防除効果に反映させることができるよう検討すべき事例 る認められている。

\section{ほ場における薬効低下（減退）現象の要因}

病害防除に施用した薬郕が常に有効であることが望ま しい，乙かし施用した薬剤が所期の目的を果さず，いわ
ゆる薬効低下（減退）現象が認められた場合，その原因 調查に必要な条件として以下の要因が考えられる。

I ．原因が耐性菌による場合

a．その病原菌がもともと耐性である場合一自然耐性

b．もともと感性であった病原菌が耐性を獲得した場 合一変異あるいは獲得耐性

c 、病原菌が耐性誘導剂に触れて耐性が上昇した場合

II . 病原菌は感性であるが植物組織側に原因がある場 合

a 、薬椷が病原菌にその有効濃度をで達しない場合

a - 1）薬剂の施用方法が不良の場合

a - 2 ）滲出物，壞死組織に病原菌がとりかとまれて いる場合

b，薬剂が植物組織内で不活化される場合

b－1）植物組織内の代謝産物による拮抗作用あるい は蛋白質と結合する場合

b-2）䤉素によって不活化される場合

b-3） その他の原因によって不活化される場合

c．環境条件の悪化に原因がある場合

c-1）異常気象によって病原菌の分布密度が異常に 高くなった場合

c-2）気象の悪化と過剩施肥によって病原菌に対す る植物体組織の抵抗力が著しく減退した場合

$\mathrm{c}-3$ ）施用薬剂の溶脱，流亡あるいは日光等による 分解が著しく促進され，病原菌と薬剂の接触時間が 著しく短くなった場合

c - 4）植物体上に泥土，塵，煙灰などが異常に蓄積 し，施用薬剤が不活化された場合

以上の要因のなかで，薬剂耐性ということは「I」に 示された場合のみに限られる。自然耐性およびプラスミ ドによる薬戍耐性の伝達によって耐性が獲得された場合 は明らかである。「Iの $\mathrm{c} 」 の$ 事例として，エリス口マ イシンが誘導戍となりうるブドウ状球菌のマクロライド 抗生物質耐性の例がある.ブドウ状球菌が $0.5 \mu \mathrm{g} / \mathrm{ml}$ 程 度の薄いエリスロマイシンに触れると, 1 時間以内にマ クロライド系抗生物質全部とリンコマイシンに高度耐性 が発現される。したがってこの後いかに高濃度の上記抗 生物質を投与しても，誘導された耐性が消失するまで， まったく無効な現象が知られているが，農薬の場合この 事例はまだ認められていない。

「II」に示された要因は薬戍耐性でない事例で，病原 菌は感性であるが，植物体組織側で薬剤の効果を減退し ていることである. 医薬領域における同様な現象とし て，病原菌は感性であるが生体組織側に原因がある場合 を生体組織側で薬歳に「不応 (nonrefractory)」というべ 
きで，耐性の用語を使うことは混乱を生じやすいと，三 橋5は述べている。

\section{薬剤耐性菌の検定法}

植物病害防除において，農薬科学の進歩は収穫の増 加，品質の向上，あるいは施設栽培を可能にした役割は 高く評価される。しかし一方において，広沉な時として 不必要にまで連用されたこれら薬剤は耐性菌の出現をう ながした，今や各種薬剤に耐性菌が増加していることか ら, 耐性菌の検定は合理的かつ的確な薬剤防除を行なう 上に必要不可欠である。

薬剤酎性菌の検定に大切なととは，三橋15)が「ある菌 のある薬剤に対する耐性を論ずる場合, 最初に必要なの は耐性度分布曲線を画くことである」と述べているよ うに，自然界に分布している病原菌の示す薬刜感受性值 の頻度分布を調べることにある．検定の目的はある病原 菌がある薬剤に感性か耐性かを知るため，ある薬剤濃度 の下で病原菌が生育するか否かを定量的に示す必要があ る. 感性と耐性は相対的なものであるが，それを区別す る境界濃度が遺伝学的におかしくなく，かつほ場におけ る防除効果が予測できる検定法を確立することが望まし い. 一方において耐性菌の検定を実施する立場から，多 くの被検菌株の薬剤感受性值を適正均一な方法で測定 し，正確に感性菌と耐性菌を判定することが必要条件で あるが，との試験法が実施可能な範囲で，検定能率の点 からも許される範囲内で簡易化したものが望ましい.

また，in vitro の実験系で薬剂感受性を測定できない 薬剂の耐性菌の検定，あるいは薬剤の使用目的が最終的 には防除効果であることを考慮すると，基本的にはほ場 における防除試験が最も基本的な検定法であろう。しか し, この方法は実験設備および労力の点から, 実施可能 な被検菌株数が限定される。そして医薬領域における耐 性菌の院内感染にみられるように, 耐性菌の環境污染の 問題を考えると, 可能な限りほ場の防除試験と相関する in vitro の検定法を探索し，採用する必要があると考え られる。

以下に現在薬剤耐性菌の検定法として採用されている 試験法について述べる.

\section{1. 寒天平板希釈法}

多数の被検菌株を同一平板に接種して，薬株間の薬剤 感受性值を正確に比較できる。薬剤感受性あるいは薬剤 の抗菌力它測定する方法として広く採用されており， その值を定量的に表わす単位として最小発育阻止濃度 (Minimal Inhibitory Concentration 以下 MIC) および最 大生育許容濃度 (Maximal Allowable Concentration 以下
MAC) がある.

この方法における実験条件の設定について, 日本化学 療法学会の MIC 測定法 ${ }^{16)}$ の要旨を以下に記す.

1. 感受性測定用培地はいずれの会社の製品でもよい が，製造会社名を明記すること。

2. 抗生物質の濃度段階は $100 \mu \mathrm{g} / \mathrm{ml}$ を基準にした 2 倍希䣋を使用する。

3. 接種用菌液は約 $10^{8} / \mathrm{ml}$ に増殖したものを用い る. 培養後長期間保存してある菌株を試験する場合, 少 なくとも 1 回以上継代培養し, 継代培養後の菌を使用す る. $10^{8} / \mathrm{ml}$ の菌液で耐性を示す場合, $10^{6} / \mathrm{ml}$ 以下の 菌液についても MIC を測定することが望ましい。

4. 判定は完全に発育が阻止された最低濃度をもって 感受性をあらわす。ただし集落が 1 個でも発育した場 合，またはきわめてうすい菌苔が発育した場合も「発育」 とみなすが，ストレプトマイシンのようなアミノグリコ シッド系抗生物質のように, 耐性変異率の高い薬剤では 対照（薬剤を含まない培地）の発育と比べて明らかに発 育が抑制された濃度以上の高濃度において，2，3の集落 が認められることがあるが，これは除外する。たとえば 次の場合 MIC は $12.5 \mu \mathrm{g} / \mathrm{ml}$ とする.

\begin{tabular}{|c|c|c|c|c|c|}
\hline 薬剤濃度 $(\mu \mathrm{g} / \mathrm{ml})$ & 3.12 & 6.25 & 12.5 & 25 & 50 \\
\hline の発育の程度 & & & & & \\
\hline
\end{tabular}

（）内は集落数

5. 感受性測定用平板の作り方は培地を溶解し，その

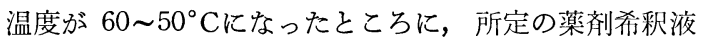
を培地の $1 / 9$ 量加えて，よくまぜ合せてペトリ皿に分注 して平板とする.

このように実験条件の設定に十分な配慮し，正確な薬 剂感受性を測定することが大切である．植物病原菌株に おいても，培地の種類によって薬剤感受性が異なること は日常経験されることで, 培地の組成, $\mathrm{pH}$ の調整 ${ }^{17)}$ 細心の注意が必要である.

\section{2. 液体培地希䣋法}

薬剤の作用機構が殺菌的か，静菌的であるかを確かめ るために, 最小殺菌濃度 (Minimal Bactericidal Concentration 以下 MBC) を測定するには便利な試験法である. ナシ黒斑病菌 (Alt. kikuchiana $)^{18)}$ ，ナシ黒星病菌 (Venturia nashicola) ${ }^{19)}$ の薬剂耐性の検定で，感性菌と耐性 菌の菌体生育阻害率が他の試験法と一致した薬剤感受性 を示した。しかしながら，この試験法は酎性变異率の高 い薬荗あるいは，接種菌量が多かったり，培養時間が長 過ぎると， mutant が発育してくるため，正確な薬剤感 受性を測定することが困難な場合もある。 


\section{3. 阻止 円法}

薬剤耐性菌の検定法として，同一平板内で薬郕間の抗 菌力を定量的に比較するには便利な方法である。薬郕耐 性細菌 ${ }^{20)}$ 抢よび系状菌の検定 ${ }^{8,21,22)}$ に採用され，通常， 阻止円形成の有無, 阻止円の直径它測定して, 感受性の 程度や耐性を判定している. 実験条件の設定については 寒天平板希橎法に準ずるが，平板の調製時に接種菌株の 生育状態が等しく, 菌量も等しくとも実駼操作の遅速に よって菌株間の正確な薬戍感受性を比較することが難し い事例もある。その他実験実施上の注意事項については 他の著書を参照されたい。

\section{4. 胞子発芽試験法}

実験操作が簡便で，試験期間が短く，純粋培養ができ ないうどんこ病菌などの薬剤感受性も比較できる利点が ある。リンゴ斑点落葉病菌 $(A l t . m a l i)^{23)}$, ナシ黒斑病 菌 (Alt. kikuchiana) $)^{24,25)}$, リンゴ黑星病菌 (Venturia inaequalis $)^{26,27)}$ ，イネいもち病菌 (Pyri. oryzae $)^{14)}$ ， キ ュウリ・メロンうどんこ病菌 (Sphaerotheca fuliginea) $)^{28)}$ の分生胞子, キク白銹病菌 (Puccinia horiana $)^{29,30)}$ の冬 胞子，小生子などについて試験が行なわれ，感性と耐性 が判定できることは報告されている。しかしながら，感 性菌々耐性菌の境界濃度を定量的に表示した研究報告は 少ない，たと光ば宇田川ら 25)はポリオキシンに対するナ シ黑斑病菌の耐性菌の検定法として，ポリオキシン 2 , 20，200 ppm と無添加区の培地上における胞子発芽状態 を観察し，薬剂耐性の程度を強，中，弱の三群に区別し て，ほ場に打ける防除指針に利用していることを報告し ている、筆者らはカスガマイシン耐性イネいもち病菌が ブラストサイジン S に交さ耐性を示し ${ }^{14)}$ ，その胞子発芽 阻害濃度を定量的に求め, 感性菌と次のようにして比較 した。標準菌株 P-2 と耐性菌 4 株のブラストサイジン $\mathrm{S}$ の胞子発芽阻害濃度定次式から $\mathrm{R} \cdot \mathrm{R}$ (Resistant Ratio）を求めると

$$
\mathrm{R} \cdot \mathrm{R}=\frac{\text { 被 検 菌(耐性菌) のE D值 }}{\text { 標準菌株（感性菌）のE D值 }}
$$

$\mathrm{ED}_{50}$ で約 4 10，ED90 で約 10 の值を示すことが認め られた。この $\mathrm{R} \cdot \mathrm{R}$ が $4 \sim 8$ の值が結核菌に対するスト レプトマイシンの感性と耐性を区別する数值 ${ }^{31)}$ と類似し ており，胞子発芽試験において子耐性菌と判定する $\mathrm{R} \cdot \mathrm{R}$ の值，あるいはその薬剤濃度を定量的に表示し，感性と 耐性の境界濃度を求めるためには多数の菌株を供試した 試験成績の蓄積が必要と考元られる，この他に胞子発芽 に対する薬理作用において，異常発芽した胞子が植物に 感染力をもつか否かを判定する基準を誤まると，感性菌 之耐性菌の境界濃度が变動し, 検定結果が防除効果に反
映しない可能性も推定されるので注意しなければならな W.

\section{5. 防 除試 験}

薬効試験において，in vitro の薬威感受性とほ場にお ける防除効果が一致することもあれば，一致しないこと もある。それゆえに耐性菌の検定法として，防除試験が 最も基本的な検定法であろう. 他の検定法に比較し実験 結果にバラッキは大きいが，最も信頼できる方法であ り, in vitro の薬剂感受性と植物体上の病害防除作用が 相関するか否かを確かめる場合にも実施されている。試 験法の種類と規模については多数の研究報告々著書があ るので省略する，ただし，防除効果のみを目的とした試 験に比較し, 耐性菌による環境污染を避けるために, 接 種源, 罹病植物の管理はきびしくする必要がある。

\section{検定実施上の注意事項}

ほ場に分布している病原菌が薬郕に感性か耐性である かを判定するために，以下の条件に注意する必要がある と考光られ。

1）正しい原因菌の把握

2）同一実験方法による薬剂感受性の測定

3）同一基準による防除効果の判定

4) 単独薬郕の施用（二種以上の薬郕併用の成績は除 $<)$

5）原因菌の薬棛感受性值（または耐性值）々小規模 試験およびほ場の防除効果と相関する検定法が望 ましい

原因菌の薬郕感受性值が正確に求められても，ほ場に おける防除効果が一致しない例は必ずしもまれではな い. 原因菌の推定で䛊っている場合, 検定法に難点があ る場合を別にすれば，不一致の原因として次のことが推 定される。

1）耐性と判定されながら防除効果が認められた場 合, 感染・増殖している病原菌の集団の中における耐性 菌の占める割合が問題になる. in vitro の試験で, 多数 の集落あるいは菌株を混ぜて検定しても，一個だけ耐性 菌であれば，それが選択的に増殖し耐性の成績が出るで あろうが，防除効果の場合，耐性菌の割合がきわめて少 なければ病状は回復し，少数の耐性菌は植物体の抵抗力 に制圧される可能性がある。 また接種菌量が多いと in vitro および in vivo の薬剤感受性が低下し，感性菌を 耐性菌と判定するおとれがある，とれは個体当たりの薬 量が少なくなることにも原因があり，細菌の場合とくに 著しい。

2）感性と判定されながら防除効果が低い原因とし 
て，薬剤施用後における耐性の誘導現象（農薬ではこの 現象はみつかっていない)，あるいは検定時間が短いと 一定時間は発育が阻止されているが，その後急激に菌が 発育する場合は検定時間を長くしてみる必要がある。そ れは薬剤によって，MIC と MBC が比較的接近してい るものと，両者がかなり離れている場合 ${ }^{32}$ が知られてい るからがある。たとえば MIC を測定するまでの時間を 2 3 倍にし, 細菌では 48 72 時間, 糸状菌では 72 120 時間培養して，薬郕の作用性を観察している報告 ${ }^{14,17) も ~}$ ある、しかしながら，培養時間が長過ぎると，ストレプ トマイシン，リフォンピシンなど耐性変異率の高い薬戍 の場合，耐性菌に変異した菌の発育を観察することにな る。その事例はキュウリ斑点細菌病菌 (Ps. lachrymans) および野菜の軟腐病菌 (Er. carotovora) に認められて いるので33)，実験条件の設定には十分な検討を加えてお く必要があろう。

3）検定精度を高める条件に被検菌株のサンプリング 方法が問題となる．多数の分離菌株を供試することが検 定精度を高める，実施可能な方法として，病害虫の発生 予察事業に採用されている，高木 ${ }^{34)} ら の$ 平面型任意系統 抽出法が望ましいと考元られる。すなわち，一筆ほ場の 4〜5 地点から各 1 菌株を分離し，40 50 筆のほ場から 合計 200 株程度を検定することによって，耐性菌の疫学 的動向が把握できるものと推定される ${ }^{13)}$.

以上の注意事項の他に検定法の問題とも関係するとと であるが，薬剤の作用性の差異も十分検討する必要があ る。たとえば薬片が直接植物体上の病原菌に接触する場 合は問題がない。しかしポリオキシンのように植物体内 および菌体内に浸透移行する薬剤に比較し, chlorothalonil のように植物体内にほとえど浸透移行しない薬剤と では，罹病組織内の病原菌の防除作用が異なる現象も観 察されると推定される。事実，カスガマイシン耐性イネ いもち病菌はブラストサイジン Sに対し，in vitro の感 受性值と防除試験の予防効果よりも治病効果に交さ耐性 を示す ${ }^{14)}$ こが認められている。したがって，薬郕と病 原菌の組合せによっては各種の試験結果を検討した後に 感性か耐性かを判定する必要もあると考えられる。

\section{薬剤耐性菌の疫学}

自然界には同一病原菌の種でいろいろな形質を発現す る菌株が分布していることから，薬戍耐性という遺伝的 特性を示す菌株も当然存在するものと推定されていた。 ある薬剂が病害防除に使用される前，または未使用地带 で耐性菌が分離されたという報告もある。たとえばスト レプトマイシンに対する耐性菌として，イネ白葉枯病菌
(Xanthomonas oryzae $)^{35)}$ ，クワ縮葉細菌病菌 (Pseudomonas mori $)^{36)}$ ，タバコ野火病菌 $(P s . \text { tabaci })^{20)}$ ，また 系状菌に打いてはべノミル耐性菌としてカンキッ青かび 病菌 (Penicillium italicum) 打よび緑かび病菌 (Pen.

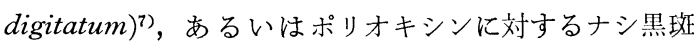
病菌 (Alt. kikuchiana) ${ }^{18,37)}$ に打いて，ポリオキシン使 用前に分離されたと推定される菌株に感受性の低いもの が存在していた。しかし一般的にはほ場に打ける薬効低 下現象をきっかけとして，その原因が耐性菌の出現によ ることから確認されている事例が多い.

わが国で1975年に10薬戍に対し13種の病原菌に耐性菌 が出現していることが報告1されている。これら耐性菌 が出現している薬羭の作用機構を調べると，従来の薬剤 に比較し殺菌作用より静菌作用を有し，生体内組織にお いて Sublethal Concentration（死なない程度の最大薬戍 濃度）の持続時間の長い薬剤が多い。一方耐性菌の出現 していない従来の重金属を含有する薬剤の場合，その施 用濃度が耐性菌の出現可能性以上の高濃度で使用されて いることが，ほ場における耐性菌の出現が問題にされな かったことも指摘 ${ }^{38}$ される。

薬剂耐性菌の疫学は薬剂を使用する立場から重要な研 究テーマである。薬剤防除を必要とするほ場で, 分布し ている菌株の薬剤感受性の疫学的動向を知らないと，所 期の防除目的は達せられず，防除費用の損失のみならず 残留毒性，微生物相の攪乱などデメリットだけが残る事 例を生じている。そこで筆者らは最近全国各地で分離さ れた植物病原菌株について, 数種薬㓮の感受性值 (MIC) を測定し，病原菌の示す薬郕感受性値が正規分布を示す か，西るいは二・三峰性の頻度分布曲線を示すか調べ た。 その結果 ${ }^{12)}$, 薬剤との接触の少ない牧草の病原菌 Pseudomonas coronafaciens var. atropurpurea の示す ストレプトマイシンおよびカスガマイシン感受性值の頻 度分布は一峰性の正規分布を示し，耐性菌は認められな かった。しかし野菜の軟腐病菌 (Erwinia carotovora) およびキュウリ斑点細菌病菌 (Ps. lachrymans) の示す ストレプトマイシン感受性值, リンゴ斑点落葉病菌 (Alt. mali）打よびナシ黑斑病菌 (Alt. kikuchiana) の示すポ リオキシン B 感受性值，イネいもち病菌 (Pyri. oryzae) の示すカスガマイシンおよびブラストサイジン $\mathrm{S}$ 感受性 值の頻度分布曲線は，それぞれ二峰性または三峰性の分 布曲線を示し，明らかに酎性菌が分布していることが認 められた。

施設栽培の普及に伴って, 発生面積と被害が増加して いる兏色かび病菌 (Botrytis sp.) の分離植物として 14 種 類, 地域別では 1 都17県から分離した菌株について調査 


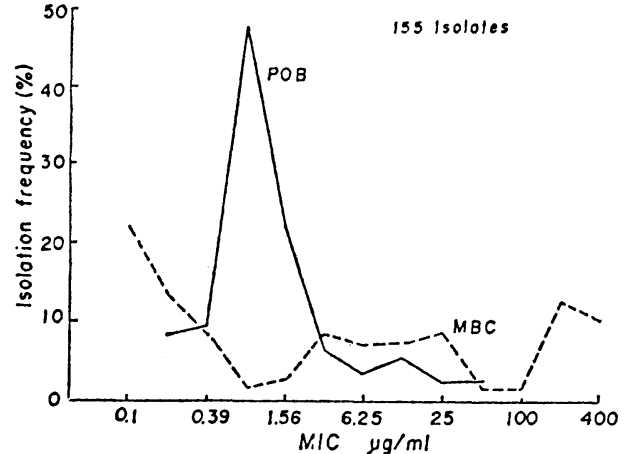

図 2 Sensitivity distribution of Botrytis sp. to polyoxin B and MBC. (Sakurai et al.)

PoB : polyoxin $\mathrm{B}$

$\mathrm{MBC}$ : carbendazim

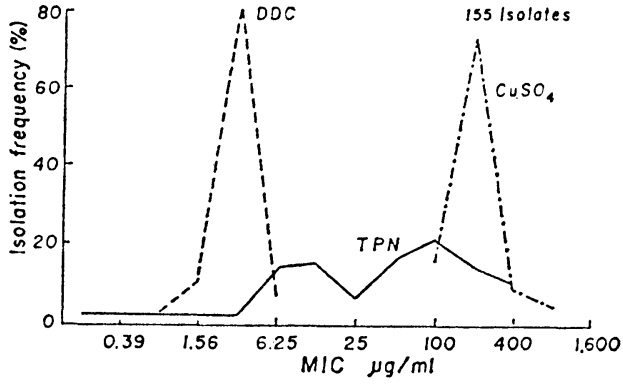

図 3 Sensitivity distribution of Botrytis sp. to TNP, DDC and $\mathrm{CuSO}_{4}$. (Sakurai et al.) TPN : chlorothalonil DDC : N-(3,5-dichlorophenyl)-1,2-dimethylcyclopropanedicarboximide (S-7131)
した結果 ${ }^{11)}$, 疫学的にも興味深い事例が認められたので 四 2 および 3 に示した。これらの図から carbendazim に 対する感性と耐性の境界濃度は MIC 值で $0.78 \mu \mathrm{g} / \mathrm{ml}$ または $1.56 \mu \mathrm{g} / \mathrm{ml}$ と推定される。そして全国的にも耐 性菌の分布密度が高率であることを示している。ついで chlorothalonil に対し感受性值の頻度分布曲線は二峰性 の分布曲線を示し，耐性菌が分布していることが認めら れたホポリオキシン Bに対する感受性值の頻度分布曲線 は一峰性を示してはいるが，感受性の低い菌株が増加の 傾向にあることが認められた。しかしながら，耐性菌の 出現が報告されていない硫酸銅および供試菌株が洗礼を 受けていないと推定される薬郕, DDC (S-7131) に対し， この病原菌の示す MIC 值の濃度範囲も狭く，明らかに 正規分布を示し，耐性菌が分布していないことが認めら れた。

薬剤散布の有無と耐性菌の分離頻度は明らかに相関す ることが，ナシ黒斑病菌の示すポリオキシンB感受性值 の頻度分布の調査から認められ ${ }^{11)}$ ，一筆ほ場内において 感性菌と耐性菌が混在していることはイネいもち病菌, リンゴ斑点落葉病菌などに認められている。しかしなが ら，Miura $ら^{9)}$ は同一罹病部から酎性菌と感性菌が分離 されなかったことを報告している。

耐性菌の出現した疫学的背景として, 西村 ${ }^{37}$ および甲 元ら ${ }^{39 \sim 42)}$ はナシ黑斑病菌におけるポリオキシン耐性菌 の場合，二十世紀梨は黒斑病菌に対し高度の罹病性であ りながら，その商品価值の高いために栽培が続けられて いる．このことは病害に対する強力な保護として，過去 の栽培経験による耕種的予防法と薬剤防除なしに経営栽 培の成り立たない果樹である，そのために薬剤防除は必
要であるが，同一薬剤の過度の連用によって耐性菌の出 現を促したと述べている。そして酎性菌の地理的分布お よび年次別推移など疫学的動向を 5 年間にわたって調査 しているが，いったん出現した耐性菌の撲滅は容易でな いことを指摘している. 三浦，伊藤ら ${ }^{43 \sim 45)}$ もイネいも ち病菌におけるカスガマイシン耐性病の疫学的調査か ら，当該薬剈の使用禁止に伴って耐性菌の分布密度は急 激に低下するが，完全に絶滅することは困難であること を報告している。

耐性菌の出現とその分布密度に関与する要因として，

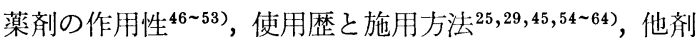
との輪用ならびに混用などがあげられる。一方病原菌自 体の要因として，生活史，増殖速度，世代交替期間およ び薬剤耐性の遺伝学的背景が関係してくる. 病害の発生 が栽培様式における環境条件によって大きく影響を受け ることから，同一植物の同一病害でも栽培法によって薬 剂の使用回数と使用量が異なるために，病原菌が薬剂耐 性化する出現頻度も当然異なってくることが考えられ る。したがって，各種の薬剤耐性菌の発生様相が薬剤の 輪用よりも連用, 露地栽培よりも施設栽培, 輸作地帯よ りも連作地帯に早く出現し ${ }^{65)}$ ，その分布密度も高い事例 が多くなっている，そこで病害防除に農薬を使用する立 場から，耐性菌出現の技術子測，耐性菌が増加する状態 の防止，あるいは病原菌が薬剤而性化する変異率を低下 させる研究のために, 疫学の果たす役割は高いものと考 えられる。

\section{薬剮耐性パターン}

病原菌の示す薬剤耐性の形質発現が一剤耐性か，多剤 
耐性であるかは病害防除上重要な問題である。ある薬剤 に耐性を示す病原菌がその薬剤と同じような作用機構を もつ薬剤に交さ耐性を示す場合と，腸内細菌の薬剤耐性 菌にみられるストレプトマイシン，クロラムフェニコー ル，第二塩化水銀など化学構造とその作用機構がまった く異なる薬剤に同時に耐性を獲得する事例がある。

植物病原菌の場合，化学構造と作用機構が類似してい るポリオキシン各成分に対して，ポリオキシン耐性ナシ 黑斑病菌 (Alt. kikuchiana) は交さ耐性を示す ${ }^{21)}$ ことか 認められている。またべノミルおよびその関連物質であ るベンズイミダゾール誘導体およびチオファネートメチ ルの間において，各薬剤はいずれも変換をうけて共通の 生成物である carbendazim を生じ，病原菌の生育を阻害 することから多くの菌に交さ耐性の事例が認められてい る.すなわち, Aspergilus ${ }^{66)}$, Botrytis ${ }^{67 \sim 73)}$, Cercospora ${ }^{74,75)}$, Colletotrichum ${ }^{76)}$, Erysiphe ${ }^{77)}$, Sphaerotheca $^{1)}$, Fusarium ${ }^{78)}$, Penicillium ${ }^{79 \sim 81)}$, Sclerotinia ${ }^{82,83)}$, Venturia $^{26,27,84,85)}$ などその病原菌の種類は多い. また 化学構造とその作用機構が異なるが交さ耐性が認められ るものに，イネいもち病菌におけるカスガマイシン耐性 菌の事例がある.この耐性菌はカスガマイシンの他にブ ラストサイジン S に交さ耐性を示す ${ }^{14)}$. この他に向ら ${ }^{86}$, 87)はキュウリ斑点細菌病菌に三剂および四剂耐性菌が存 在していることを報告している，上杉ら ${ }^{88,89}$ は実験室内 で有機リン剤耐性イネいもち病菌に負相関交さ耐性の現 象を報告している。このように病原菌にはいろいろな薬 郕耐性の形質発現を示す菌株が存在するととも推定され る. 事実, 灰色かび病菌 (Botrytis sp.) の示す薬剤感受 性值 (MIC) を測定し，その結果を図 4 に示したように

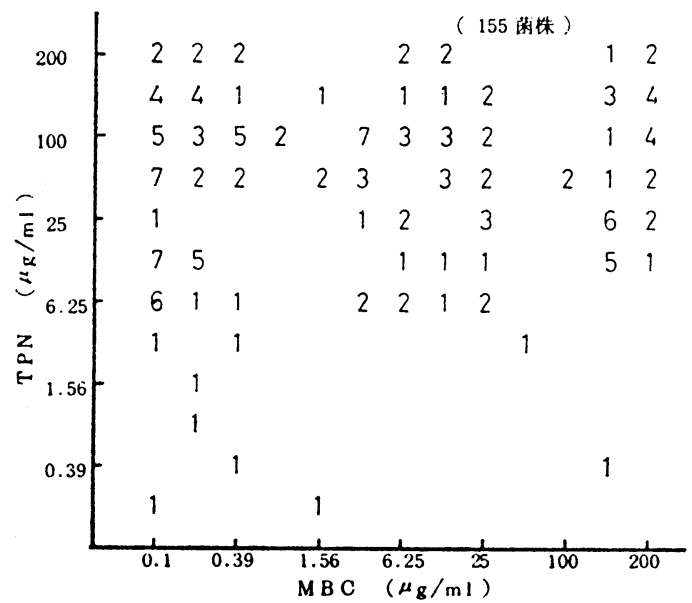

図 4 灰色かび病菌の MBC および TPN の MIC 值 の相関図 (桜井ら) carbendazim 耐性菌のなかで chlorothalonil に耐性を示 す菌株もあり，多郕耐性化の傾向が認められている。

\section{薬剤耐性の遺伝的背景と疫学}

感性菌群および耐性菌群の集団に属するそれぞれの菌 株が示す薬剤に対する性状は一定で，その子孫細胞に伝 わる遺伝的特性をもっている。薬剤耐性の形質発現にお ける遺伝的背景が耐性菌の伝播および疫学的動向に及ぼ す影響は大きい，薬剤耐性の形質発現が突然変異（遺伝 子突然変異および染色体異常）による場合は，その变異 率も低く約 $10^{-8}$ 程度で耐性菌の伝播は菌の増殖に比列 する。しかしながら，耐性の形質導入が感染的に伝達す るものにプラスミド（細胞質性遺伝因子）がある。プラ スミド (Plasmid) は物理的に細菌細胞の染色体とは分離 して細胞内に存在し, その状態で細胞に維持される遺伝 単位で, 正常の細菌細胞の増殖・生長に不可欠なもので はなく，多くの場合これが細胞から吅失し，また新しく 獲得されても細胞自体の生存には影響がないものであ る.このプラスミドのなかで薬剤耐性の形質導入の役割 を果たしている因子が，R因子と呼ばれ，耐性の形質を 菌と菌の接合によって伝達し, 細菌細胞内で増殖し $10^{-2}$ $\sim 10^{-6}$ の頻度で感染的に伝達していく. R因子の寄主域 が広いことは医学・農学它問わず有害微生物の疫学上重 要な問題である.

植物病原菌株間で，菌と菌の接合によって薬戍耐性の 形質が伝達することは報告されていない。しかしなが ら，腸内細菌由来の R因子が植物病原細菌に伝達するこ

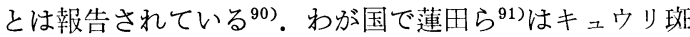
点細菌病菌 (Ps. lachrymans) が緑膿菌 (Ps. aeruginosa) 由来の R因子の受容菌ならびに供与菌となりうることを 報告している。その実験結果の一部を表 1 に示した。今 後植物病原菌における薬剤耐性の遺伝的背景の研究にお いて, 薬剤耐性の遺伝因子, 形質発現, 形質導入および伝 達に関する分野の進歩, 発展が期待されるところである.

\section{ほ場分離耐性菌と実験室内耐性菌}

試験管内で薬郕との接触によって，実験室内耐性菌は 比較的容易にえられる。薬剤耐性の形質獲得前と獲得後 の性質について，同一菌株で相互に比較できることから 実験材料としては便利である。乙かし薬剂が多量に施用 された後に，自然界に現われた耐性菌と実験室内耐性菌 の耐性機構，耐性形質の遺伝的背景が本質的に異なる場 合が多いようである．植物病原菌の実験室内耐性菌はそ の母株に比較し，薬戍耐性以外の性状が異なったり，薬 剂耐性度(MAC) が異常に高いことが認められている18). 
表 1 緑膿菌 (Ps. aeruginosa) 由来 R因子のキュウリ斑点細菌 病菌 (Ps. lachrymans) への伝達頻度（蓮田ら）

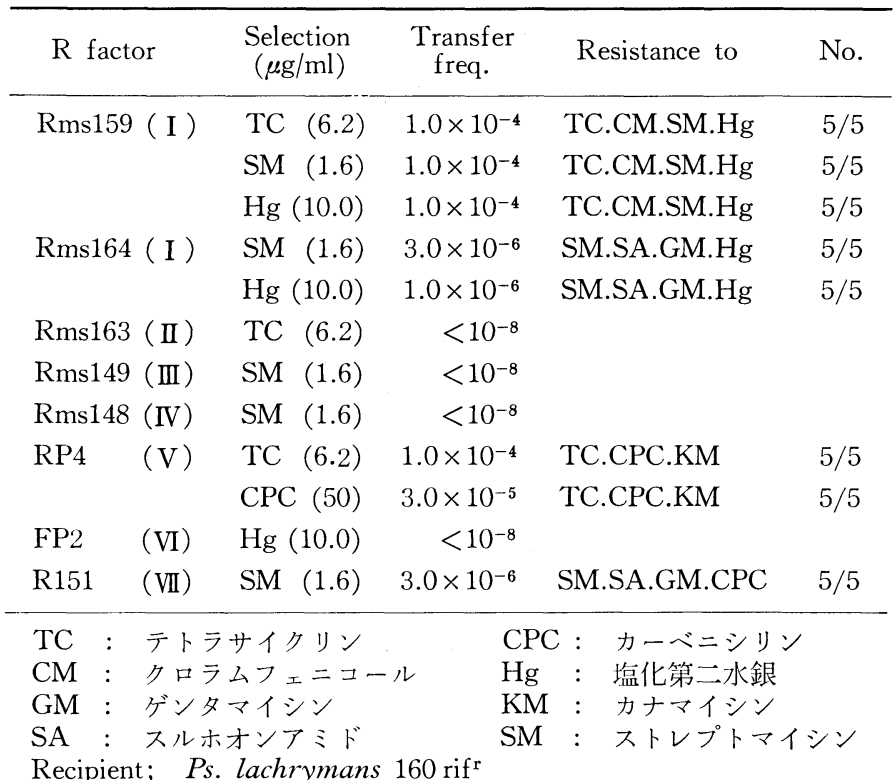

薬戍耐性菌の疫学的調査において，そ の薬刘感受性值の頻度分布から, 高率の 頻度で而性菌が検出され，薬効が期待さ れないほ場で，その薬剤は有効であった と反論されることもあるかもしれない。 しかし，それは場で耐性菌が分布し， 植物に感染していても病勢が必ず進展す るとは限らないし，植物組織に打ける薬

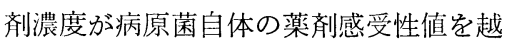
えたりポリオキシン耐性ナシ黑斑病 菌 ${ }^{18)}$ でみられたように，菌と薬凨が長時 間接触するような場合は予想以上の防除 効果を示し，また「ほ場的感性」13) の現 象もあり，収穫の経済的損失を受けない 場合もあるのではなからうか。したがっ て薬効が優れているからといって，無批 判に連用，乱用することをつつしみ，現 在残っている数少ない薬剤に再び耐性菌 を出現させたり，あるいは増加させるこ とは絶対に避けなければならない。

病害防除に薬剂があることは必要条件である。而性菌 が出現したり，増加する状態を防止するために，疫学的 調査研究にもとづいた使用規制が必要であり，また耐性 菌の疫学的動向を熟知した上で，薬剤の選択と使用法を 決定する必要があるう。

今後の而性菌対策として，新しい防除薬剤の開発と既 知薬剂の改良などの研究があげられよう。しかしなが ら，光合成を行なう能力もない病原菌類が，その旺盛な 生命力と環境に適応するすぐれた能力を具只ている事実 を考慮するならば，ほ場で病害防除儂薬を使用する立 場から, 最初に必要なことは病原菌の薬郕耐性の検定法 とその疫学的調查研究ではなからうか. それらの研究成 果がほ場における防除効果に反映し， あるいは耐性菌出 現の技術予測に役立つものと考元られる。

最後に耐性菌が出現している薬凨も，その耐性菌が分 布していない地域において，優れた防除効果を示してい る.したがって耐性菌の出現頻度を抑えるためには, 薬 郕の施用回数をできる限り少なくすることが必要であ る. そのために耕種的防除法の確立と, 病原菌の分布密 度を低下させるために, 感染源となる罹病個体の除去, 埋没などによってほ場衛生に注意を配ること。また病原 菌が薬戍而性化する変異率を低下させるための研究とし て, 各種薬郕の混合施用および輪用について検討する必 要があるものと思われる。
功したとはいえないのではないかという場合も推定され る. 


\section{引用 文 献}

1）飯田 格：植物防疫 29, 163 (1975)

2）上杉康彦：同上 29，167 (1975)

3）桑原章吾：第15回日本化学療法学会東日本支部総 会，シンポジウム“感性と耐性”資料, 1968

4）山崎輝男ら：現代農薬講座 I, 朝倉書店, p. 135 1971

5）三橋 進：第15回日本化学療法学会東日本支部総 会，シンポジウム“感性と耐性”資料，1968

6) S. G. Georgopoulos et al.: Plant Dis. Reptr. 57, 321 (1973)

7) T. Kuramoto: ibid. 60, 168 (1976)

8）片桐政子ら：日植病報 40, 106 (1974)

9) H. Miura et al.: 同上 42, 117 (1976)

10) 兴井 寿ら：同上 42, 107 (1976)

11）桜井 寿ら：日本植物防疫協会, 薬郕耐性菌に関 するシンポジウム講演要旨, 41 (1976)

12) H. Sakurai et al.: J. Antibiotics 29, 1230 (1976)

13）桜井 寿: 植物防疫 29, 206 (1975)

14）桜井 寿ら： 農薬検査所報告 15，82（1975）

15）三橋 進：薬剤と耐性菌，南江堂， p. 43，1970

16）日本化学療法学会：Chemotherapy 23, No. 8, 12 (1975)

17）山村宏志ら：日植病報 41，303（1975）

18）桜井 寿ら：農薬検査所報告 14，54（1974）

19）山口 昭ら：日本植物防疫協会, 薬剂酎性菌に関 するシンポジウム講演要旨, 10 (1976)

20）前田 進ら： 秦野たばこ試報 70，91 (1971)

21）島田德治ら：農薬検査所報告 12，96（1972）

22）馬場洋子：日植病報 42,373（1976）

23）大沼幸男ら：北日本病害虫研究会報 24, 70 (1973)

24）島田德治ら：農薬検査所報告 13，37 (1973)

25）宇田川英雄：植物防疫 29, 189 (1975)

26）西田 勉ら：日植病報 41, 127 (1975)

27） 沢村健三：植物防疫 29, 187 (1975)

28）平根誠一：同上 29, 377 (1975)

29）我孫子和雄：同上 29，197（1975）

30）我孫子和雄ら：日植病報 41，100（1975）

31）青柳昭雄：第15回日本化学療法学会東日本支部総 会, シンポジウム“感性と耐性”資料, 1968

32) 小酒井望：最新医学 19, 743 (1964)

33）桜井 寿：（未発表）

34）高木信一ら：病害虫発生予察特別報告 9, 1 (1962)

35）脇本 哲ら：日植病報 28, 153 (1963)

36）高橋幸吉： 植物防疫 29, 199 (1975)

37）西村正暘ら：植物防疫 26, 157 (1972)

38) D. R. Mackenzie et al.: Phytopathology 61, 458 (1971)

39）甲元啓介ら：日植病報 40,220

40）三宅英夫ら：同上 41，100

41）甲元啓介：日本植物病理学会「植物病理化学談話 会」資料 p. 51， 1975

42）甲元啓介：農薬 23，54（1976）

43）三浦春夫ら：日植病報 40,220 (1974)

44）伊藤 弘ら：日植病報 40,220 (1974)

45） 三浦春夫： 植物防疫 29, 183 (1975)
46）中村広明ら：農薬検査所報告 8，21（1968）

47) K. Ohmori: J. Antibiotics A20, 109 (1967)

48）上杉康彦ら；装技研報告 C23，93（1969）

49）我孫子和雄ら：日植病報 39, 173（1973）

50）薬師寺国人ら：同上 37, 191 (1971)

51）小泉銘冊ら：園試興津年報 7, 23（1971）

52）小泉銘冊ら：同上 8, 28 (1972)

53）小泉銘冊ら：園試報告 B12, 245（1972）

54） 三浦春夫ら：日植病報 41，302（1975）

55）上杉康彦ら：同上 41，303(1975)

56）大沼幸男ら：同上 41，304（1975）

57） 三浦春夫ら：同上 41，415（1975）

58）木曾 皓：日本植物防疫協会，薬剤耐性菌に関す るシンポジウム講演要旨, 1 (1975)

59）伊藤征男ら：日植病報 42, 372（1976）

60） 三浦春夫ら：同上 42，372（1976）

61）牛山欽司：同上 42, 374（1976）

62）山口武夫ら：同上 42, 372（1976）

63）杉本利哉ら：日本植物防疫協会, 薬剂耐性菌に関 するシンポジウム講演要旨， 1 (1976)

64）山本 磐：同上，同上，17（1976）

65）管原寿一; 私信

66) A. Hastie et al.: J. Gen. Microbiol. 67, 371 (1971)

67) G. J. Bollen et al.: Neth. J. Pl. Path. 77, 83 (1971)

68）山本 磐：植物防疫 29, 194 (1975)

69）高梨和雄：日植病報 42, 65 (1976)

70) 竹内好子ら：同上 42,65 (1976)

71）手塚信夫ら：同上 42,98 (1976)

72）手塚信夫ら：同上 42, 373 (1976)

73) G. J. Bollen et al.: Neth. J. Pl. Path. 78, 55 (1972)

74) E. M. Clark et al.: Phytopath. 64, 1476 (1974)

75) R. H. Littrell: Phytopath. 64, 1377, 49 (1974)

76) P. J. Griffee: Trans. Br. mycol. Soc. 60, 433 (1973)

77) M. Vargas: Phytopath. 63, 1366 (1973)

78) J. B. Schooley et al.: Phytopath. 61, 816 (1971)

79) G. J. Bollen: Neth. J. Pl. Path. 77, 187 (1971)

80) P. R. Harding: Pl. Dis. Reptr. 56, 256 (1972)

81) J. J. Smoot et al.: Pl. Dis. Reptr. 58, 933 (1974)

82) C. W. Goldenberg et al.: Phytopath. 63, 201 (1973)

83) C. G. Warren et al.: ibid. 64, 1139 (1974)

84）沢村健三ら：日植病報 42，70（1976）

85）石井英夫ら：同上 42，373 (1976)

86）向 秀夫ら：同上 42, 61 (1976)

87）向 秀夫ら: 同上 42, 113 (1976)

88) Y. Uesugi et al.: Agric. Biol. Chem. 38, 907 (1974)

89）上杉康彦ら：日植病報 40，255（1974）

90) W. V. Panopoulos et al.: Phytopath. 65, 380 (1976)

91）蓮田勝美ら：日植病報 42, 107 (1976)

92）三橋 進：薬剤と耐性菌，南江堂，p. 175，1970 